\title{
Partial rootzone drying: effects on growth and fruit quality of field-grown grapevines (Vitis vinifera)
}

\author{
Tiago P.dos Santos ${ }^{\mathrm{A}}$, Carlos M. Lopes ${ }^{\mathrm{A}}$, M. Lucília Rodrigues ${ }^{\mathrm{A}}$, Claudia R. de Souza $^{\mathrm{B}}$, \\ João P. Maroco ${ }^{\mathrm{B}, \mathrm{C}}$, João S. Pereira ${ }^{\mathrm{A}}$, Jorge R. Silva ${ }^{\mathrm{A}}$ and M. Manuela Chaves ${ }^{\mathrm{A}, \mathrm{B}, \mathrm{D}}$

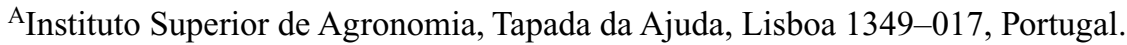 \\ ${ }^{\mathrm{B}}$ Laboratório de Ecofisiologia Molecular, Instituto de Tecnologia Química e Biológica, \\ Apartado 127, Oeiras 2780-901, Portugal. \\ CInstituto Superior de Psicologia Aplicada, Rua Jardim do Tabaco, 34, Lisboa 1149-047, Portugal. \\ DCorresponding author; email: mchaves@isa.utl.pt
}

\begin{abstract}
A study to assess the effects of the Partial Rootzone Drying (PRD) irrigation strategy in comparison to other irrigation systems was carried out in southern Portugal in two field-grown grapevines varieties, Moscatel and Castelão. We addressed the question of whether by regulating growth and plant water use, the PRD system would enable an equilibrated vegetative development, leading to a favourable capture of solar radiation for photoassimilate production and, at the same time to provide an optimum environment for fruit maturation. Three irrigation schemes were applied in addition to the non-irrigated (NI) vines: partial root drying (PRD), 50\% of crop evapotranspiration (ETc), supplied to only one side of the root system while the other one was allowed to dry, alternating sides every 15 days; deficit irrigated (DI), 50\% ETc supplied, half to each side of the root system and full irrigated (FI, 100\% ETc). During the whole season FI plants of both varieties exhibited a high leaf predawn water potential $\left(\psi_{\text {pd }}\right.$, $c a-0.2 \mathrm{MPa}$ ) while a progressive decline was observed in NI plants, reaching $\psi_{\text {pd }}$ values near $-0.7 \mathrm{MPa}$ at the end of August. PRD and DI presented intermediate values. PRD vines exhibited a stronger control over vegetative growth as compared with DI and FI plants. This was expressed by lower values of total leaf area at harvest, leaf layer number, canopy wideness and water shoots number, allowing a higher light interception at the cluster zone that induced an improvement in some berry quality characteristics. Watering had no significant effects on sugar accumulation in the berries but led to a favourable increase in the must titratable acidity, mainly in Castelão. Whereas in DI and FI treatments berry skin anthocyanins and phenols content were always lower than in NI, in PRD there was either no reduction or the reduction was much lower than in the other irrigation treatments. Water use efficiency (WUE) was increased by about $80 \%$ in PRD and DI when compared with FI, as a result of almost similar yields in the three treatments. Yield gains of irrigated plants in relation to NI were modest, explained by the rainy spring in both years.
\end{abstract}

Keywords: berry quality, canopy density, grapevine, irrigation, partial rootzone drying.

\section{Introduction}

Irrigation of commercial vineyards is becoming widespread to secure and stabilise production. In regions with a Mediterranean type of climate, unfavourable patterns of precipitation occur frequently and may lead to periods of marked plant water deficits in vines growing without irrigation. These water stress periods may reduce yield and compromise berry quality. These effects, depending on the time of occurrence and intensity of drought period, are mainly produced by a shortening of shoot elongation (Matthews et al. 1987), a decreased carbon assimilation
(Chaves and Rodrigues 1987; Schultz 1996), poor reproductive development (Matthews and Anderson 1989), with decreased berry growth (Ojeda et al. 2001) and an accentuated leaf senescence and abscission, contributing to fruit sunburn (Kliewer et al. 1983; Smart and Robinson 1991).

Vegetative growth has a higher sensitivity to water deficits than gas exchange and fruit growth. The inhibition of leaf growth is often the earliest response to moderate water stress (Shackel et al. 1987; Lu and Neumann 1998). It is well known that in plants in drying soil, shoot growth can be limited as a result of hydraulic insufficiency,

Abbreviations used: DI, deficit irrigated; ETc, crop evapotranspiration; ETo, potential evapotranspiration; FI, full irrigated; LLN, leaf layer number; NI, non-irrigated; PRD, partial rootzone drying; WUE, water use efficiency. 
i.e. decreased shoot water status, and of chemical signalling, involving transfer of chemical information from root to the shoots via the xylem (Davies et al. 1994). There is evidence suggesting that shoot growth can decline due to root-toshoot signalling mechanisms even in the absence of an unaltered tissue water condition (Davies and Zhang 1991; Dodd et al. 1996; Bacon et al. 1998). In grapevine, Shackel et al. (1987) showed that leaf expansion was not strongly dependent on cell turgor within a range of plant water deficits, suggesting the importance of metabolic growth regulation in controlling wall loosening and mechanical cell wall properties.

Irrigation improves leaf physiological activity and plant growth rate. Nevertheless, excessive water supply can lead to a high canopy density, which may negatively affect fruit quality, due to competition for assimilates between growing shoots and berries and influence on fruit microclimate, namely reducing light penetration in the cluster zone. Dense canopies can also negatively affect sugar, anthocyanins and total phenols contents, since their accumulation is strongly dependent on light availability during ripening (Crippen and Morrison 1986; Dokoozlian and Kliewer 1996; Keller and Hrazdina 1998). Moreover, very dense canopies provide poor air circulation and enhance the incidence of major grapevine diseases (Smart 1994), which affect yield and quality.

Vegetative growth can be managed through the regulated deficit irrigation (RDI), where watering input is either reduced or withheld for specified periods of time (Chalmers et al. 1986; McCarthy 1997; Battilani 2000). Meanwhile, a new irrigation technique called Partial Root Drying (PRD) has been developed, allowing control of plant growth and transpiration, without the unsuitable severe water stress periods that can occur in RDI (Dry et al. 1996; During et al. 1997, Loveys et al. 2000). The PRD technique is based on direct sensing of soil moisture status by roots and it requires that the root-zone to be simultaneously exposed to both wet (half of the root system) and drying soil (the other root half). In this way, roots of the watered side maintain the plant water status, while dehydrating roots send chemical signals to the shoots via the xylem. These signals will hypothetically control the vegetative vigour and stomatal conductance. In this work we addressed the question of whether PRD would combine the favourable conditions for carbon assimilation obtained with irrigation with the improved microenvironment for fruit maturation that occur when moderate water stress inhibits vegetative growth. PRD was thus compared with rain fed vines (NI), the traditional irrigation treatments of fully irrigated plots, FI (minimum water deficit) and the treatment receiving the same amount of water as PRD but distributed to both sides of the root system (DI). We also aimed to compare PRD effects on two contrasting varieties, as far as yield and type of grape (white/red) is concerned, the cvv. Moscatel and Castelão.
The measurements made comprised plant water relations, vine growth, canopy density, yield and fruit composition of the two grapevine varieties growing under field conditions.

\section{Materials and methods}

\section{Field conditions and plant material}

This research was conducted during two seasons (2000 and 2001) in a commercial vineyard at the Centro Experimental de Pegões, southern Portugal (70 km south of Lisbon). The climate is of the Mediterranean type, with hot and dry summers and mild winters, having an average annual rainfall of $550 \mathrm{~mm}$, with $400 \mathrm{~mm}$ falling during the winter months. The soil is derived from podzols, mostly sandy and with a clay rich (low permeability) horizon at $c a 1 \mathrm{~m}$ depth. The two varieties of Vitis vinifera L. studied were Moscatel (syn. Muscat of Alexandria), a white variety used for wine and table grapes and Castelão, a red wine variety, both grafted on 1103 Paulsen rootstock in 1997 and 1996 respectively. The vines were trained on a bilateral Royat Cordon system using a vertical shoot positioning with a pair of movable wires and spur pruned. The mean node number retained at pruning was 10 and 12 for Moscatel and 14 and 16 for Castelão in 2000 and 2001, respectively. Standard cultural practices in the region were applied to all treatments. Four foliar fertilisation treatments were made in both years (between June and August) for both varieties, corresponding to a total of $2.6 \mathrm{~kg} \mathrm{~N}$ and $9.2 \mathrm{~kg}$ of $\mathrm{K}\left(\mathrm{K}_{2} \mathrm{O}\right) \mathrm{ha}^{-1}$ year $^{-1}$. Shoots were trimmed at about $30 \mathrm{~cm}$ above the higher fixed wire, two to three times between bloom and veraison. The vineyard has a planting density of 4000 vines per hectare with vines spaced $1.0 \mathrm{~m}$ within and $2.5 \mathrm{~m}$ between rows.

\section{Irrigation and experimental design}

Irrigation was applied with drip emitters, two per vine, independently controlled and positioned $30 \mathrm{~cm}$ from the vine trunk, out to both sides of the row. Watering was applied according to the crop evapotranspiration (ETc), estimated from the potential evapotranspiration (ETo), which was calculated from the Class A pan evaporation and using the crop coefficients $\left(\mathrm{K}_{\mathrm{c}}\right)$ proposed by Prichard (1992). Each irrigated treatment was equipped with a time clock valve assembly to control water delivery. Four treatments were imposed: non-irrigated but rain-fed (NI); partial root drying (PRD, 50\% of ETc supplied to only one side of the root system with $4 \mathrm{~L} \mathrm{~h}^{-1}$ drip emitters with the other one allowed to dry, alternating sides every 15 days); deficit irrigated (DI, $50 \%$ of the ETc supplied simultaneously to both sides of the row with $2 \mathrm{~L} \mathrm{~h}^{-1}$ drip emitters) or full irrigated (FI, $100 \%$ of the ETc supplied simultaneously to both sides of the root system with $4 \mathrm{~L} \mathrm{~h}^{-1}$ drip emitters). Watering was done twice a week, from fruit set (mid-June) until one week before harvest (end of August). The total water amount supplied to FI plants between mid-June and the end of August was $144 \mathrm{~mm}$ (360 L per vine) and $168 \mathrm{~mm}$ (420 L per vine) for 2000 and 2001 respectively. The PRD and the DI vines received half of that quantity.

The experimental design was a latin square with four treatments and four replications per treatment. Each replicate (plot) had $15-20$ vines.

\section{Plant water relations and growth measurements}

Pre-dawn leaf water potential $\left(\psi_{\mathrm{pd}}\right)$ was measured weekly from the beginning of berry development until harvest, i.e. from the end of June to the second week of September. Measurements were carried out on one adult leaf of six replicate plants from each treatment using a Scholander pressure chamber (Model 1000; PMS Instrument Co., Corvallis, OR, USA). Leaves were enclosed in a plastic bag, immediately severed at the petiole and sealed into the humidified chamber for determination of the balancing pressure. 
Leaf area from the main shoot and lateral shoot (arising from prompt buds on the main shoot) were estimated periodically in count shoots from bud break onwards. The area of single leaves was estimated using a model based on the measurements of the length of the two main lateral leaf veins (Carbonneau 1976). The model was calibrated by measuring vein length and leaf area on randomly selected leaves of all sizes, using a leaf area meter (LI-3000; LI-COR Lincoln, NE, USA). Leaf area per shoot ( 8 shoots per treatment) was assessed in a non-destructive way, by a model with four variables: shoot length, leaf number and area of the largest and the smallest leaf (Lopes and Pinto 2000). Leaf area per plant was estimated by multiplying the average shoot leaf area by the average shoot number.

Canopy density was assessed using point quadrat analysis (Smart and Robinson 1991), by inserting a needle at regular intervals into the fruit zone. Eighty insertions per treatment (twenty per plot) were made and leaf layer number, percentage of exposed clusters and interior leaves were calculated. Light at the cluster zone was measured in sunny days at midday using a Sunflek ceptometer (model SF-40, Delta T Devices Ltd, Cambridge, UK). The values of incident photosynthetic photon flux density (PPFD) were expressed in percentage of a reference PPFD, measured over the canopy top. At winter pruning, shoot number and weight were also taken to determine the shoot weight. Water use efficiency (WUE) was estimated as the ratio between yield and the amount of supplied water.

\section{Yield and fruit quality}

Berry ripening was followed periodically, from veraison (around end of July) until harvest (beginning of September). Sampling was done according to Carbonneau (1991), by using a 200 berries sample per plot, collected in all vines of the same treatment (3-4 berries per cluster). The berries collected represented all positions within the clusters. Subsamples from the 200 berries sample were used for analysis of $\mathrm{pH}$, soluble solids ( ${ }^{\circ} \mathrm{Brix}$ ) by refractometry and titratable acidity by titration with $\mathrm{NaOH}$. Total phenols were determined by spectrophotometry, measuring UV absorption at $280 \mathrm{~nm}$ (RibéreauGayon et al. 1972). Anthocyanins were measured by the sodium bisulphite discoloration method (Ribéreau-Gayon and Stonestreet 1965).

At the end of each season (11 of September in 2000 and on 13 of September in 2001) yield components and fruit quality were assessed, following manual harvesting and weighing the production on-site. Yield per vine and clusters per vine were recorded for all vines from each plot. Fruit composition was analysed as previously described.

\section{Data analysis}

Statistical data analysis was performed by analysis of variance (ANOVA). Tukey's HSD tests were carried out to test the significance of differences between treatment means using the STATISTICA software (ver. 5.0, Statsoft Inc., Tulsa, OK, USA).

\section{Results}

\section{Climate and plant water relations}

Figure 1 shows that 2000 and 2001 had a higher rainfall during the Spring months (March-May) than the 30-year average. However, air temperature followed the average pattern in both years. Figure 2 shows that during the two growing seasons, FI plants of both varieties always exhibited a high and almost constant $\psi_{\text {pd }}(>-0.2 \mathrm{MPa})$, while a progressive decline was observed in NI plants, which attained mean values between $-0.6 \mathrm{MPa}$ and $-0.7 \mathrm{MPa}$ at end of August, in the two years. Nevertheless, in 2001, NI plants of Castelão had an earlier decrease of $\psi_{\mathrm{pd}}$ comparatively to NI plants of Moscatel. In the two years, DI and PRD plants of Moscatel maintained lower values of $\psi_{\text {pd }}$ than FI plants, but significant differences only occurred after the middle of August. In Castelão, PRD and DI vines had values of $\psi_{\text {pd }}$ intermediate as compared with those of FI and NI plants.

\section{Vegetative growth and canopy density}

As the node number retained at pruning was the same for all treatments, no differences in the count shoot number per vine were observed (Table 1). However, the average individual shoot weight measured at winter pruning (Table 1) was, in general, lower in PRD and NI than in FI and DI. Similar differences were observed in the number of water shoots (developed on the old woody stem) measured in 2001, with the PRD values lower than those of the other irrigated treatments and similar to those of NI vines (Table 1). As for the pruning weight per vine (i.e. shoot biomass collected at pruning), FI vines had the highest values, which were

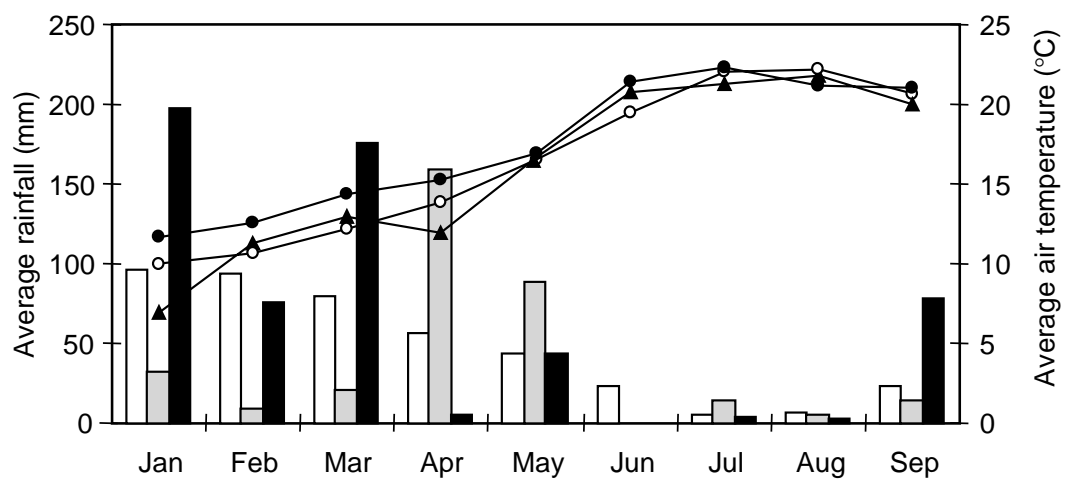

Fig. 1. Total rainfall (bars) and monthly mean air temperature (lines) at the experimental site during the seasons of 2000 and 2001 and average values of 30 years (1954-1984). Average total rainfall (mm) for period 1954-1984 ( $\square$ ); total rainfall for $2000(\square)$; total rainfall for $2001(\boldsymbol{\square})$. Average monthly temperatures $\left({ }^{\circ} \mathrm{C}\right)$ for period $1954-1984(\bigcirc)$, $2000(\mathbf{\Delta})$ and $2001(\mathbf{O})$. 


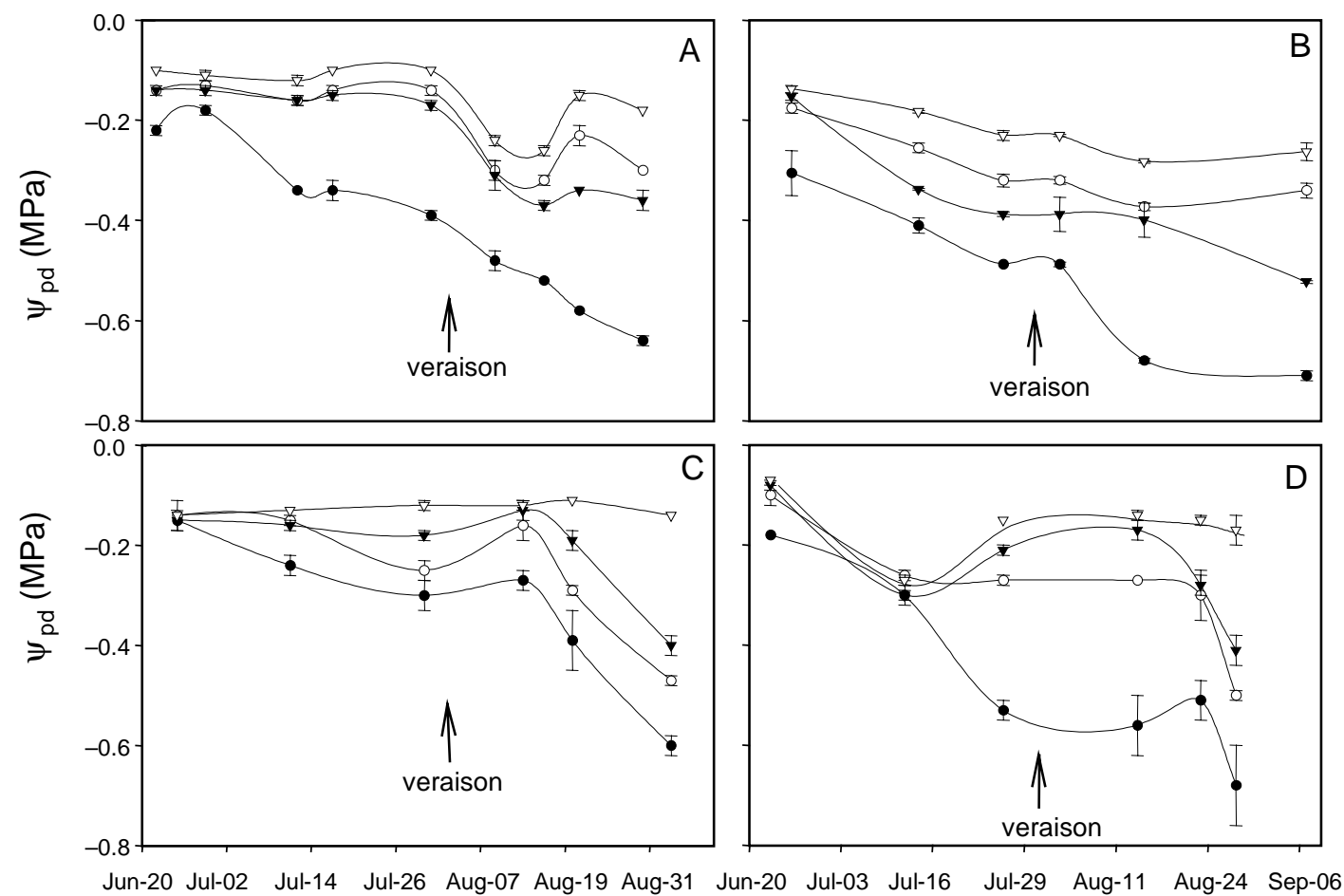

Fig. 2. Seasonal evolution of pre-dawn leaf water potential for all water treatments: NI $(\boldsymbol{\bullet})$, PRD $(\bigcirc)$, DI $(\boldsymbol{\nabla})$ and FI $(\nabla)$, in Moscatel $(A, C)$ and Castelão $(B, D)$ during 2000 and 2001 growing seasons, respectively. Each point represents the average of 8 measurements with standard error. Bars not visible indicate standard error smaller than the symbol.

significantly different from the NI vines (Table 1). In Castelão, DI and FI showed no significant differences in the pruning weight, whereas the pruning weight of PRD vines was significantly lower than that of FI. Pruning weight was different between the two varieties, with Castelão having the highest values.
The total leaf area in both varieties had significantly higher values $(P<0.05)$ in FI than in NI vines or in the other irrigated treatments at veraison (Fig. 3). Between veraison and harvest, while FI vines presented an increase in total leaf area, NI vines showed a decrease due to basal leaf senescence. At harvest, PRD plants showed a total leaf area

Table 1. Yield, vigour, water use efficiency and fruit composition at harvest of Moscatel and Castelão grapevines under four water treatments (NI, PRD, DI, FI), determined in the 2000 and the 2001 experiments.

Different letter suffixes show statistically significant differences at $P<0.05$. The term na signifies the parameter was not measured

\begin{tabular}{|c|c|c|c|c|c|c|c|c|c|c|c|c|c|c|c|c|}
\hline & \multicolumn{8}{|c|}{ Moscatel } & \multicolumn{8}{|c|}{ Castelão } \\
\hline & \multicolumn{4}{|c|}{2000} & \multicolumn{4}{|c|}{2001} & \multicolumn{4}{|c|}{2000} & \multicolumn{4}{|c|}{2001} \\
\hline & NI & PRD & DI & FI & NI & PRD & DI & FI & NI & PRD & DI & FI & NI & PRD & DI & FI \\
\hline \multicolumn{17}{|l|}{ Yield components } \\
\hline Cluster number per vine & $15.6 \mathrm{a}$ & $15.0 \mathrm{a}$ & $15.8 \mathrm{a}$ & $15.3 \mathrm{a}$ & $18.2 \mathrm{a}$ & $18.5 \mathrm{a}$ & $20.0 \mathrm{a}$ & $19.6 \mathrm{a}$ & $15.5 \mathrm{a}$ & $15.6 \mathrm{a}$ & $17.2 \mathrm{a}$ & $16.2 \mathrm{a}$ & $19.9 \mathrm{a}$ & $18.8 \mathrm{a}$ & $19.9 \mathrm{a}$ & $21.5 \mathrm{a}$ \\
\hline Cluster weight (g) & $475.9 b$ & $515.9 \mathrm{~b}$ & $502.0 \mathrm{~b}$ & $592.8 \mathrm{a}$ & $472.2 \mathrm{a}$ & $506.0 \mathrm{a}$ & $473.4 \mathrm{a}$ & $502.5 \mathrm{a}$ & $114.9 \mathrm{~b}$ & $141.1 \mathrm{a}$ & $122.3 \mathrm{ab}$ & $151.5 \mathrm{a}$ & $203.9 b$ & $245.8 \mathrm{a}$ & $236.2 \mathrm{a}$ & $236.2 \mathrm{a}$ \\
\hline Yield (kg per vine) & $7.4 \mathrm{~b}$ & $7.7 \mathrm{~b}$ & $7.9 \mathrm{ab}$ & $9.0 \mathrm{a}$ & $8.3 \mathrm{~b}$ & $9.1 \mathrm{ab}$ & $9.2 \mathrm{ab}$ & $9.7 \mathrm{a}$ & $1.8 \mathrm{a}$ & $2.2 \mathrm{a}$ & $2.1 \mathrm{a}$ & $2.5 \mathrm{a}$ & $4.1 \mathrm{~b}$ & $4.6 \mathrm{ab}$ & $4.7 \mathrm{ab}$ & 5.1 \\
\hline WUE $\left(\mathrm{g}\right.$ berry $\mathrm{L}^{-1}$ ) & na & $42.1 \mathrm{a}$ & $43.2 \mathrm{a}$ & $24.6 b$ & na & $43.4 \mathrm{a}$ & $43.7 \mathrm{a}$ & $23.1 \mathrm{~b}$ & na & $11.1 \mathrm{a}$ & $10.6 \mathrm{a}$ & $6.3 b$ & na & $22.5 \mathrm{a}$ & $22.8 \mathrm{a}$ & $12.8 \mathrm{~b}$ \\
\hline \multicolumn{17}{|l|}{ Vigour } \\
\hline Shoot number per vine & $11 \mathrm{a}$ & $11 \mathrm{a}$ & $9 \mathrm{a}$ & $9 \mathrm{a}$ & $13 \mathrm{a}$ & $12 \mathrm{a}$ & $13 \mathrm{a}$ & $12 \mathrm{a}$ & $14 b$ & $16 \mathrm{ab}$ & $16 \mathrm{ab}$ & $17 \mathrm{a}$ & $16 \mathrm{a}$ & $18 \mathrm{ab}$ & $20 \mathrm{~b}$ & $19 b$ \\
\hline Shoot weight $(\mathrm{g})$ & $49.0 \mathrm{~b}$ & $53.4 \mathrm{~b}$ & $64.3 \mathrm{a}$ & $69.0 \mathrm{a}$ & $36.4 \mathrm{~b}$ & $41.2 b$ & $42.7 b$ & $50.8 \mathrm{a}$ & $70.1 \mathrm{c}$ & $89.8 b$ & $102.5 \mathrm{ab}$ & $105.8 \mathrm{a}$ & $64.9 \mathrm{~b}$ & $67.8 b$ & $76.8 \mathrm{a}$ & $77.8 \mathrm{a}$ \\
\hline Pruning weight $\left(\mathrm{kg} \mathrm{vine}^{-1}\right)$ & $0.52 b$ & $0.56 \mathrm{ab}$ & $0.57 \mathrm{ab}$ & $0.64 \mathrm{a}$ & $0.46 b$ & $0.51 \mathrm{ab}$ & $0.52 \mathrm{ab}$ & $0.58 \mathrm{a}$ & $1.1 \mathrm{c}$ & $1.4 \mathrm{bc}$ & $1.6 \mathrm{ab}$ & $1.8 \mathrm{a}$ & $1.1 \mathrm{~b}$ & $1.2 \mathrm{~b}$ & $1.5 \mathrm{a}$ & $1.5 \mathrm{a}$ \\
\hline Water shoots $(\%)$ & na & na & na & na & $8.0 \mathrm{a}$ & $9.4 \mathrm{a}$ & $12.7 \mathrm{~b}$ & $12.9 \mathrm{~b}$ & na & na & na & na & $11.2 \mathrm{a}$ & $14.0 \mathrm{a}$ & $21.5 b$ & $20.8 b$ \\
\hline \multicolumn{17}{|l|}{ Fruit Composition } \\
\hline $\begin{array}{l}\text { Total soluble solids } \\
\text { ( }{ }^{\circ} \text { Brix) }\end{array}$ & $21.0 \mathrm{a}$ & $21.8 \mathrm{a}$ & $20.6 \mathrm{a}$ & $20.6 \mathrm{a}$ & $17.7 \mathrm{a}$ & $18.6 \mathrm{a}$ & $17.9 \mathrm{a}$ & $18.4 \mathrm{a}$ & $23.4 \mathrm{a}$ & $24.1 \mathrm{a}$ & $23.5 \mathrm{a}$ & $23.1 \mathrm{a}$ & $22.4 \mathrm{a}$ & $22.3 \mathrm{a}$ & $23.0 \mathrm{a}$ & $22.2 \mathrm{a}$ \\
\hline Titratable acidity $\left(\mathrm{g} \mathrm{L}^{-1}\right)$ & $3.5 b$ & $3.6 \mathrm{~b}$ & $3.8 \mathrm{ab}$ & $3.9 \mathrm{a}$ & $4.0 \mathrm{a}$ & $4.0 \mathrm{a}$ & $4.0 \mathrm{a}$ & $4.2 \mathrm{a}$ & $3.48 \mathrm{c}$ & $3.90 \mathrm{~b}$ & $4.08 \mathrm{~b}$ & $4.48 \mathrm{a}$ & $3.3 \mathrm{a}$ & $4.3 b$ & $4.1 \mathrm{~b}$ & $3.9 \mathrm{ab}$ \\
\hline $\mathrm{pH}$ & $4.07 \mathrm{a}$ & $4.07 \mathrm{a}$ & $3.99 b$ & $3.97 \mathrm{~b}$ & $3.95 \mathrm{a}$ & $3.95 \mathrm{a}$ & $3.91 \mathrm{a}$ & $3.90 \mathrm{a}$ & $4.22 \mathrm{a}$ & $4.22 \mathrm{a}$ & $4.16 \mathrm{a}$ & $4.07 \mathrm{a}$ & $4.2 \mathrm{a}$ & $4.1 \mathrm{a}$ & $4.2 \mathrm{a}$ & $4.1 \mathrm{a}$ \\
\hline \multicolumn{5}{|c|}{ Anthocyanins (mg dm ${ }^{-3}$ must) } & & & & & $646.4 \mathrm{a}$ & $490.2 b$ & $453.7 \mathrm{bc}$ & $351.2 \mathrm{c}$ & $703.6 \mathrm{a}$ & $445.2 b$ & $438.4 b$ & $364.0 \mathrm{~b}$ \\
\hline Phenols (IFT) & $15.6 \mathrm{a}$ & $15.8 \mathrm{a}$ & $13.0 \mathrm{~b}$ & $12.8 \mathrm{~b}$ & $17.6 \mathrm{a}$ & $16.8 \mathrm{a}$ & $17.2 \mathrm{a}$ & $16.8 \mathrm{a}$ & $21.8 \mathrm{a}$ & $17.0 \mathrm{~b}$ & $15.9 \mathrm{bc}$ & $12.2 \mathrm{c}$ & $14.2 \mathrm{a}$ & $13.6 \mathrm{ab}$ & $10.4 \mathrm{c}$ & $11.4 \mathrm{bc}$ \\
\hline
\end{tabular}



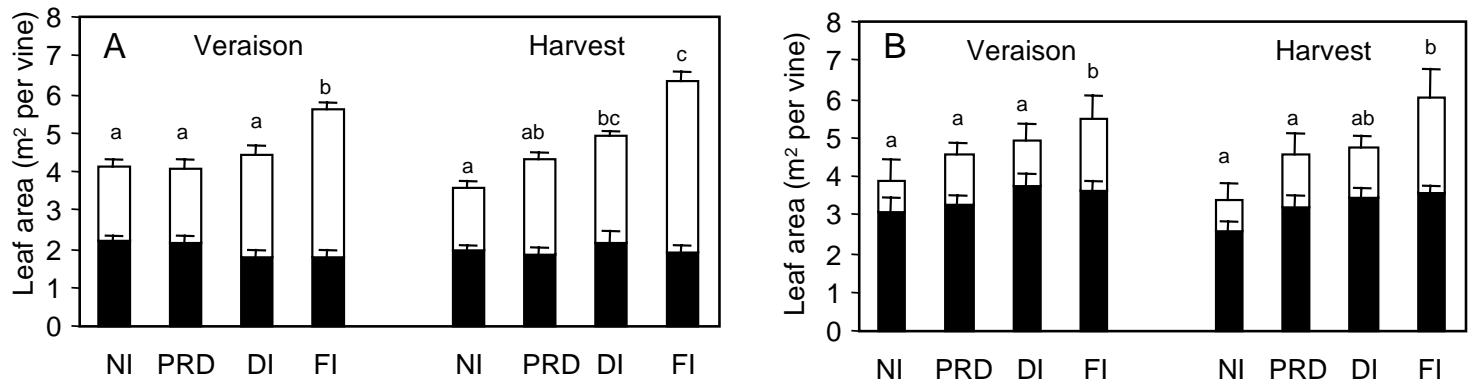

Fig. 3. Main ( $\square)$ and lateral leaf area $(\square)$ of Moscatel $(A)$ and Castelão $(B)$ grapevines under four water treatments (NI, PRD, DI, FI), measured at veraison and at harvest in 2000 experiment. Values shown represent the mean of 8 measurements with standard error. Different letter suffixes show statistically significant differences of total leaf area at $P<0.05$.

similar to the NI plants, while DI plants had values not significantly different of those of FI and PRD plants. Because irrigation started after the first trimming, the main shoot leaf area was similar in the different watering treatments in both varieties. Therefore, the difference of total leaf area observed between treatments was due to differences in the lateral shoot leaf area. At harvest, these leaves accounted for a percentage of the total leaf area per plant ranging from $72.8 \%$ in FI to $45.3 \%$ in NI for Moscatel and from $41.2 \%$ in FI to $23.9 \%$ in NI for Castelão. A higher total leaf area was nevertheless observed in Castelão when compared with Moscatel. For example, at veraison in Castelão, it was ca $45 \%$ higher in NI and PRD and 105\% higher in DI and FI than in Moscatel.

The canopy wideness at the fruit zone was measured at veraison, mid-ripening and harvest in Castelão variety (Fig. 4). In both years the pattern was similar, with NI plants having the narrowest canopy and DI and FI the widest. PRD showed intermediate canopy wideness, with no significant differences from NI in the second year of the experiment.

Leaf layer number (LLN) was lower in NI and PRD as compared with DI and FI treatments (Fig. 5). One exception occurred in 2000 in Moscatel, where the LLN value was significantly higher in PRD than in NI. As a consequence of the low LLN, NI and PRD vines showed in both seasons at veraison a higher percentage of sun-exposed clusters than the other irrigated treatments FI and DI (Fig. 6). In fact, for Moscatel, the light measured at the cluster zone was $62 \%$ higher in PRD and 27\% higher in DI plants in comparison to FI vines, whereas in Castelão, which had a wider canopy, this increase was $37 \%$ and $14 \%$ for PRD and DI vines, respectively.

\section{Yield components and fruit composition}

The FI treatment induced a significant yield increase when compared with NI in Moscatel (Table 1). PRD and DI presented intermediate values, which were for PRD

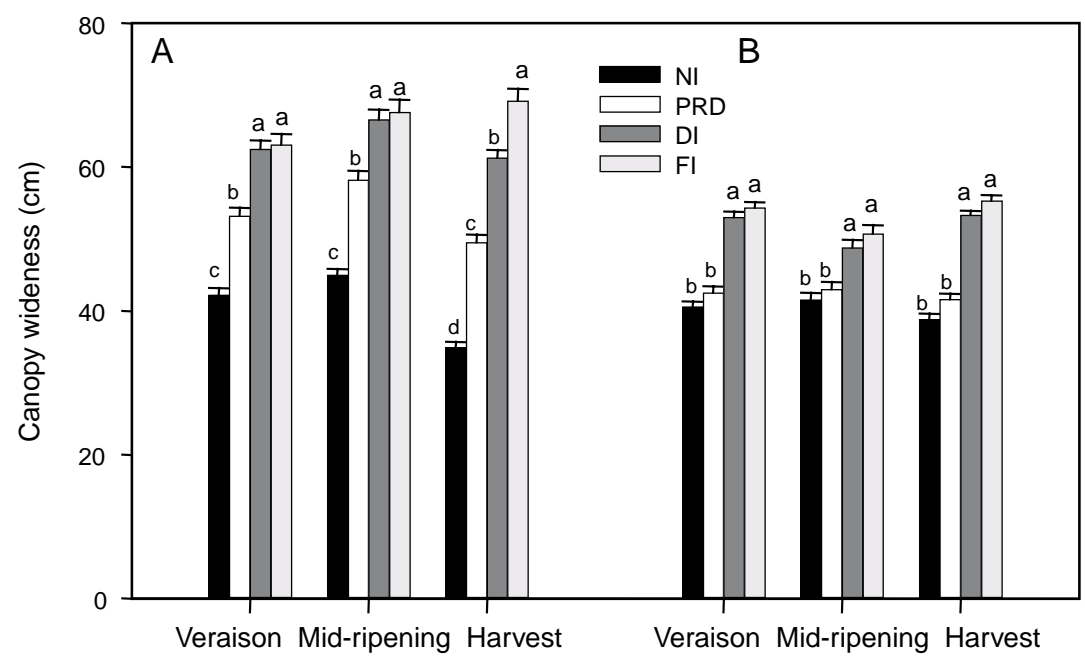

Fig. 4. Canopy wideness of Castelão grapevines under four water treatments (NI, PRD, $\mathrm{DI}, \mathrm{FI}$ ), measured during the ripening period (veraison, mid-ripening and harvest), in the $2000(A)$ and the $2001(B)$ experiments. Values shown represent the mean of 100 measurements with standard error. Different letter suffixes show statistically significant differences at $P<0.05$. 


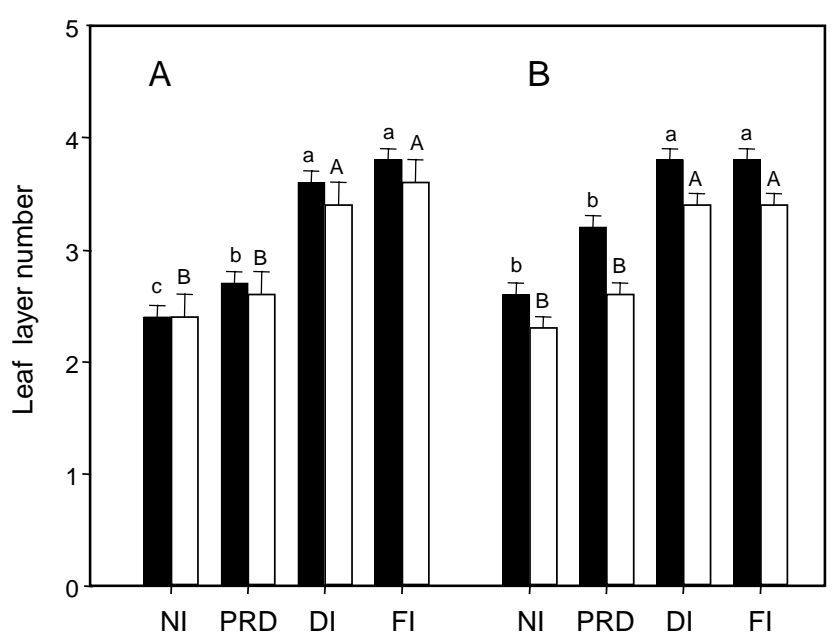

Fig. 5. Leaf layer number of Moscatel ( $\square$ ) and Castelão ( $\square$ ) grapevines under four water treatments (NI, PRD, DI, FI), measured at veraison in the $2000(A)$ and the $2001(B)$ experiments. Values shown represent the mean of 80 measurements with standard error. Different letter suffixes show statistically significant differences at $P<0.05$.

significantly different from FI in 2000. Castelão showed a much lower yield than Moscatel and a large variability between the two years of the experiment (doubled in 2001). Nevertheless, the effects of water treatments on yield were quite similar in 2001 to those of Moscatel, although no significant differences were observed in 2000 . The yield differences among treatments were mainly due to the cluster weight since the cluster number was independent of the treatment, because it was set prior to the start of irrigation.

The yield/pruning weight ratio was much lower in Castelão (1.3-3.8) than in Moscatel (13.8-18.0). As the

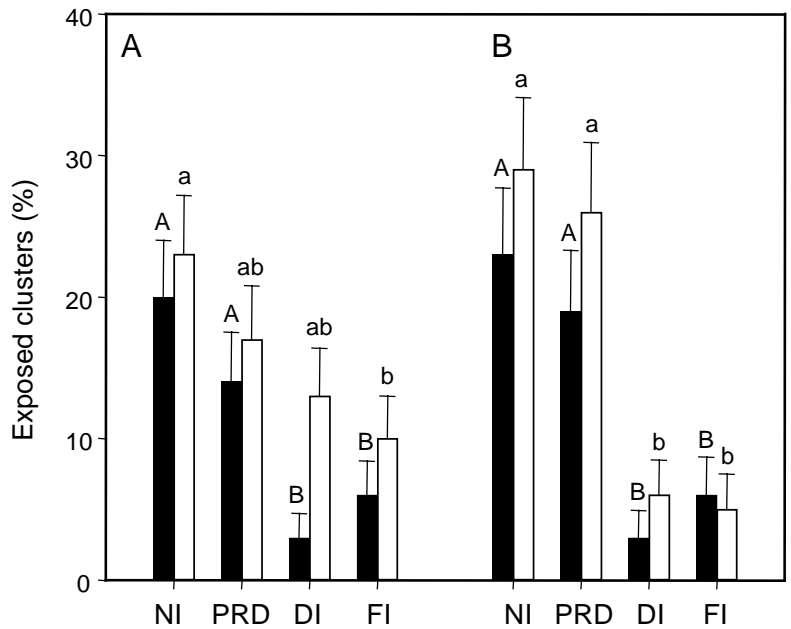

Fig. 6. Percentage of sun-exposed clusters of Moscatel grapevines under four water treatments (NI, PRD, DI, FI), determined at veraison (ם) and at maturation ( $\square$ ), in the $2000(A)$ and the 2001 (B) experiments. Different letter suffixes show statistically significant differences at $P<0.05$. yield was similar in the different irrigation treatments in both years and varieties, WUE in PRD and DI treatments was almost the double of that observed in FI, which received the double amount of water.

Fruit quality changed with irrigation treatments. When compared with NI, irrigation had no significant effect on berry total soluble solids ( ${ }^{\circ}$ Brix) in both seasons and varieties, but led to a significant increase in the titratable acidity of the must in Castelão (Table 1). In Moscatel, the latter effect was only observed in FI in the year 2000. In Castelão, the red wine variety, irrigation induced a significant negative effect on the berry skin anthocyanins and phenol concentration. In both years, however, PRD plants presented the highest values of anthocyanins among the irrigated treatments, whereas in 2001 the phenol concentrations did not differ between PRD and NI plants. In the white variety Moscatel the effects of watering on phenols were negligible. Only in 2000 was a decline in phenols observed in DI and FI plants, with PRD maintaining values similar to NI plants.

\section{Discussion}

The present study was done in a region where moderate water stress is common and severe drought periods can occur. In this region grapevine irrigation is not yet a common practice but in the last ten years, as a consequence of very dry weather, the growers began to install conventional drip irrigation systems with the objectives of stabilising yield and wine quality from year to year. In the two years of our experiment the annual precipitation was close to the average for the period 1941-1998 (683 mm) and rainfall in the late spring was higher than the average. As a consequence, the non-irrigated vines were subjected only to a mild stress and the effect of irrigation was not of the magnitude expected in dry years. This abundance of soil moisture during the season resulting from the unusually high rainfall in the spring of both years is also reflected in the small differences observed in leaf water potential between FI and the two deficit irrigated treatments (PRD and DI) that received only $50 \%$ of the water given to FI (see Fig. 2).

Compared with standard conventional irrigation techniques, one important advantage of PRD is the better control of vegetative growth (Loveys et al. 2000). Our data showed that among the irrigated treatments PRD vines had the lowest leaf area associated with lateral shoots, as already reported by Dry et al. (2001), as well as the lowest leaf layer number, canopy wideness, percentage of water shoots and shoot weight. The differences between PRD values and FI were all statistically significant, whereas between PRD and DI this was true except for total leaf area. Although the restriction of growth in PRD might be partly a response to the fraction of water applied, and therefore with effects similar to DI, specific hormonal effects may explain results 
such as the decrease in water shoots. In fact, cytokinins are known to influence lateral branching and the application of the synthetic cytokinin benzyl adenine was shown to reverse the reduction in lateral shoot development observed under PRD treatment (Dry et al. 2001). Differential effects of PRD and DI on stomatal conductance and transpiration observed in the same trial also support the hormonal mediated effects induced under PRD (de Souza et al. 2003).

Another possible effect of PRD is the promotion of increased root growth in depth, as reported by Dry et al. $(2000,2001)$ for the variety Riesling. In fact, a greater abundance of roots in deeper soil layers in PRD vines as compared with full-irrigated ones was found, although the total amount of roots did not vary. This would allow a thorough utilisation of water stored in the soil as the dry season progresses.

The reduction in vigour was observed in the two varieties studied, in spite of marked differences in vigour between them, Moscatel having a low potential shoot vigour (Dry and Loveys 1998) compared with Castelão, which possesses a high potential shoot vigour (Dias et al. 1990). This suggests a consistent effect of the PRD treatment, as was observed in experiments in Australia with a range of varieties (Dry et al. 2001).

The control of vegetative growth in PRD induced an increase in bunch exposure as compared with FI vines, which can favour wine quality by the well-known effects of a better canopy microclimate and improved pest control on fruit composition (Smart and Robinson 1991; Dokoozlian and Kliewer 1996).

The yield of Castelão, one of the most important Portuguese red-wine varieties, was much lower and more influenced by the year than Moscatel. Moreover, Castelão is a variety very sensitive to 'coulure' (Dias et al. 1990), a physiological disorder characterised by non-setting of fruit. The unfavourable temperature and humidity that occurred during the flowering period in the year 2000 was responsible for the very low yield observed in that year. As a consequence of the low fruit yield and a high investment on vegetative growth the ratio yield/pruning weight obtained in Castelão (1.3-3.8) was very low, i.e. below the values suggested by Bravdo et al. (1985) for a balanced vine. The opposite was observed in Moscatel with very high yield/pruning weight values (13.8-18.0) suggesting that the vines were over-cropped (Bravdo et al. 1985). Indeed, in 2001, when the highest yield was obtained, total berry soluble solids did not reach the normal values for Moscatel variety at this region ( $\mathrm{ca} 22^{\circ}$ Brix), confirming an overcropping effect.

With the exception of the year 2000 in Moscatel, the yield differences between the FI and the other two irrigation treatments were not significant even though FI received twice as much water as PRD or DI. This means that berry growth was not affected by the very mild water stress observed under PRD and DI. This is explained by the fact that this mild stress was imposed during ripening, after the period where berry size is most sensitive to water stress (Williams and Matthews 1990; Santos 2000). As a result of the $50 \%$ reduction in the amount of water applied, WUE (amount of fruit produced per unit of water applied) was increased by about $80 \%$ in PRD and DI treatments when compared with FI. These results, combined with the absence of important fruit quality differences between irrigation treatments, underline the interest of the deficit irrigation strategies to make more efficient use of limited supplies of water without affecting yield and wine quality.

Irrigation did not significantly affect berry sugar accumulation, results that contrast with those obtained by other authors who observed either an increase (Schultz 1996; Lopes et al. 2001) or a decrease (Pire and Ojeda 1999) in berry sugars induced by irrigation. This suggests that berries were a preferential sink for carbohydrates under very mild water deficits (as occurred in DI and PRD) and even in the moderate drought stress observed in NI vines in the two years of the experiment. Conversely, the titratable acidity of the must increased in irrigated plants, which is a common response to irrigation (Williams and Matthews 1990; Santos 2000), an effect that can be considered beneficial for the wines of the region that usually present a lack of acidity.

In the red variety, Castelão, irrigation induced a significant reduction in total anthocyanins and phenols relatively to NI vines. This may be a consequence of the increased water supply for berry growth, which decreased the skin to flesh ratio, and of the indirect effects of the increase in canopy density and cluster shading (Williams and Matthews 1990; Van Leeuwen and Seguin 1994; Nadal and Arola 1987; Lopes et al. 2001). In our experiment, because no differences in yield were observed, it seems that the main reason for the higher concentrations of total anthocyanins and phenols in NI as compared with the irrigated treatments was the better light microclimate measured at the cluster zone and the higher percentage of exposed clusters. Among the three irrigated treatments, the lowest reduction in skin anthocyanins and total phenols was observed in PRD vines, however the values were not always significantly different from those of DI.

In conclusion, our results from these two years of experiments showed that both PRD and DI irrigation strategies enabled the same reduction of water use, as compared with the fully irrigation treatment receiving the full replacement of crop evapotranspiration, with small or non-significant effects on yield. Although in our experiment PRD induced a marked reduction in vigour and slightly enhanced fruit quality in comparison with FI, differences from DI were not always statistically significant. This may not encourage the growers to substitute the conventional DI-type irrigation practices for the PRD, as installation costs are higher and the implementation is more difficult than that 
of DI. Nevertheless, the significant differences in canopy density and light microclimate at the cluster zone between PRD and DI, suggest that in years with low spring rainfall, PRD could provide better fruit quality than DI especially in red varieties. These results may be also important with the objectives of stabilising yield and wine quality from year to year.

\section{Acknowledgments}

We thank the Direcção Regional da Agricultura da Região Oeste (DRARO), especially the Centro Experimental de Pegões for the experimental vineyard facilities, We also thank A. S. Rodrigues, N. Conceição and E. Breia for the help on data collection and G. Rodrigues for the technical assistance in measuring fruit composition parameters. This research was funded by the UE project IRRISPLIT (ICA-1999-10026).

\section{References}

Bacon MA, Wilkinson S, Davies WJ (1998) pH-regulated leaf cell expansion in droughted plants is abscisic acid dependent. Plant Physiology 118, 1507-1515.

Battilani A (2000) Application of the regulated deficit of irrigation to grapevines (Vitis vinifera) in a sub-humid area. Proceedings of the third international symposium on irrigation of horticultural crops. Acta Horticulturae 537, 887-893.

Bravdo B, Hepner Y, Loinger C, Tabacman H (1985) Effect of irrigation and crop level on growth, yield and wine quality of Cabernet Sauvignon. American Journal of Enology and Viticulture 36, 132-139.

Carbonneau A (1976) Principes et méthodes de mesure de la surface foliaire. Essai de caractérisation des types de feuilles dans le genre Vitis. Annales Amélioration des Plantes 26, 327-343.

Carbonneau A (1991) Observation sur vigne: codification des donnés agronomiques. Rivista di Viticoltura e di Enologia 4, 37-45.

Chalmers DJ, Burge G, Jerie PH, Mitchell PD (1986) The mechanism of regulation of 'Bartlett' pear fruit and vegetative growth by irrigation withholding and regulated deficit irrigation. Journal of the American Society of Horticultural Science 111, 904-907.

Chaves MM, Rodrigues ML (1987) Photosynthesis and water relations of grapevines growing in Portugal - response to environmental factors. In 'Plant response to stress - functional analysis in Mediterranean ecosystems'. (Eds JD Tenhunen, FM Catarino, OL Lange and WC Oechel) pp. 379-390. (Springer-Verlag: Berlin)

Crippen Jr. DD, Morrison JC (1986) The effects of sun exposure on the phenolic content of Cabernet Sauvignon berries during development. American Journal Enology and Viticulture 37, 243-247.

Davies WJ, Zhang J (1991) Root signals and the regulation of growth and development of plants in drying soil. Annual Review of Plant Physiology and Plant Molecular Biology 42, 55-76.

Davies WJ, Tardieu F, Trejo CL (1994) How do chemical signals work in plants that grow in drying soil? Plant Physiology 104, 309-314.

de Souza CR, Maroco JP, dos Santos TP, Rodrigues ML, Lopes CM, Pereira JS, Chaves MM (2003) Partial rootzone drying: regulation of stomatal aperture and carbon assimilation in field-grown grapevines (Vitis vinifera cv. Moscatel). Functional Plant Biology 30, 653-662.

Dias JE, Pereira CAD, Cunha JPB (1990) Catálogo das castas da Região do Ribatejo, Oeste e Península de Setúbal. (Instituto da Vinha e do Vinho, Divisão de Cadastro Vitícola: Lisboa)
Dodd IC, Stikic R, Davies WJ (1996) Chemical regulation of gas exchange and growth of plants in drying soil in the field. Journal of Experimental Botany 47, 1475-1490.

Dokoozlian NK, Kliewer WM (1996) Influence of light on grape berry growth and composition varies during fruit development. Journal of the American Society for Horticultural Science 121, 869-874.

Dry PR, Loveys BR (1998) Factors influencing grapevine vigour and the potential for control with partial rootzone drying. Australian Journal of Grape and Wine Research 4, 140-148.

Dry PR, Loveys BR, Botting D, During H (1996) Effects of partial root-zone drying on grapevine vigour, yield, composition of fruit and use of water. In 'Proceedings of the 9th Australian wine industry technical conference'. Adelaide. (Eds C Stockley, A Sas, R Johnstone and T Lee) pp. 126-131. (Winetitles: Adelaide)

Dry PR, Loveys BR, During H (2000) Partial drying of the rootzone of grape. I. Transient changes in shoot growth and gas exchange. Vitis 39, 3-7.

Dry PR, Loveys BR, McCarthy MG, Stoll M (2001) Strategic irrigation management in Australian vineyards. Journal International de Science de la Vigne et du Vin 35, 129-139.

During H, Loveys BR, Dry PR (1997) Root signals affect water use efficiency and shoot growth. Acta Horticulturae 427, 1-14.

Keller M, Hrazdina G (1998) Interaction of nitrogen availability during bloom and light intensity during veraison. II. Effects on anthocyanin and phenolic development during grape ripening. American Journal of Enology and Viticulture 49, 341-349.

Kliewer WM, Freeman BM, Hossom C (1983) Effect of irrigation, crop level and potassium fertilization on Carignane vines. I. Degree of water stress and effect on growth and yield. American Journal of Enology and Viticulture 34, 186-196.

Lopes C, Pinto PA (2000) Estimation de la surface foliaire principale et secondaire d'un sarment de vigne. Progrés Agricole et Viticole 117, 160-166.

Lopes C, Vicente-Paulo J, Santos T, Rodrigues ML, Barroso J, Chaves MM (2001) An attempt to quantify grapevine water stress in a Mediterranean environment. In 'Proceedings XIIth Journées GESCO' 1, pp. 43-48. (AGRO Montpellier: Montpellier)

Loveys BR, Dry PR, Stoll M, McCarthy MG (2000) Using plant physiology to improve the water efficiency of horticultural crops. Acta Horticulturae 537, 187-197.

Lu Z, Neumann PM (1998) Water-stressed maize, barley and rice seedlings show species diversity in mechanisms of leaf growth inhibition. Journal of Experimental Botany 49, 1945-1952.

Matthews MA, Anderson MM (1989) Reproductive development in grape (Vitis vinifera L.): responses to seasonal water deficits. American Journal of Enology and Viticulture 40, 52-60.

Matthews MA, Anderson MM, Schultz HR (1987) Phenologic and growth responses to early and late season water deficits in Cabernet Franc. Vitis 26, 147-160.

McCarthy MG (1997) The effect of transient water deficit on berry development of Shiraz Vitis vinifera L. Australian Journal Grape Wine Research 3, 102-108.

Nadal M, Arola L (1987) Effects of limited irrigation on the composition of must and wine of Cabernet Sauvignon under semiarid conditions. Vitis 34, 151-154.

Ojeda H, Deloire A, Carbonneau A (2001) Influence of water deficits on grape berry growth. Vitis 40, 141-145.

Pire R, Ojeda M (1999) Vegetative growth and quality of grapevine 'Chenin blanc' irrigated under three pan evaporation coefficients. Fruits 54, 135-139.

Prichard TL (1992) A volume balance approach to quality wine grape irrigation. In 'Viticultural practices'. (Eds MA Walker and WM Kliewer) pp. 12-23. (University of California: Davies) 
Ribéreau-Gayon J, Stonestreet E (1965) Le dosage des anthocyanes dans le vin rouge. Bulletin. Société Chimique de France 9, 2649-2652.

Ribéreau-Gayon J, Peynaud E, Sudraud P, Ribéreau-Gayon P (1972) 'Traité d'Enologie sciences et techniques du tin. Tome 1 - analyse et control des vins.' (Dunod: Paris)

Santos TP (2000) Influência da rega no comportamento agronómico e fisiológico da videira (Vitis vinifera L.), na casta 'Aragonez', no Alentejo. Relatório do trabalho de fim de curso de Engenharia Agronómica (ISA: Lisboa)

Schultz HR (1996) Water relations and photosynthetic responses of two grapevine varieties of different geographical origin during water stress. Acta Horticulturae 427, 251-266.

Shackel KA, Matthews MA, Morrison JC (1987) Dynamic relation between expansion and cellular turgor in growing grape (Vitis vinifera L.) leaves. Plant Physiology 84, 1166-1171.

Smart RE (1994) The effect of manipulating grapevine vigor and canopy microclimate on yield, grape composition and wine quality. Doctor of Science thesis, University of Stellenbosch, South Africa.
Smart RE, Robinson M (1991) 'Sunlight into wine. A handbook for winegrape canopy management.' (Winetitles: Adelaide)

Van Leeuwen C, Seguin G (1994) Incidences de l'alimentation en eau de la vigne appreciée par l'etat hydrique du feuillage, sur le developpment de l'appareil végétatif et la maturation du raisin (Vitis vinifera variéte Cabernet franc, Saint-Emilion 1990). Journal International des Sciences de la Vigne et du Vin 28, 81-110.

Williams LE, Matthews MA (1990) Grapevine. In 'Irrigation of agricultural crops. Agronomy monographs no. 30'. (Eds BJ Stewart and DR Nielsen) pp. 1019-1055. (ASA-CSSA-SSSA: Madison, WI)

Manuscript received 5 September 2002, accepted 16 October 2002 